\title{
Medicine and the Culture of Command: the Case of Malaria Control in the British Army during the two World Wars
}

\author{
MARK HARRISON*
}

Perhaps more than any other disease, malaria serves as a potent symbol of the struggle between humankind and the natural world. Scientific and technical advances-from Ross's identification of the malaria vector to the application of DDT during the Second World War-have promised much but have so far failed to provide any lasting solution to the devastation caused by the disease. Yet at the close of the Second World War it was confidently expected that malaria could be not only controlled but eradicated, since newly-developed drugs and insecticides had seemingly paved the way for Allied victory in Italy, South East Asia, and the Far East.

The official histories of the Allied medical services, written in the first decade or so after 1945, were justly proud of this achievement and celebrated the work of the scientists and medical officers that had effected it. But this triumphalism never entirely obscured a more critical rendering of events, which saw the successes of military medicine not as the inevitable outcome of scientific progress but as a hard-won battle over military ignorance. The medical officer was portrayed as an heroic figure, battling against "red tape" and incompetent commanders, whose cause was vindicated by the "victory" over malaria and ultimately over the Axis Powers.

These histories are free of the distortion and bias which characterizes so many official histories of the First World War but they are unsatisfactory for a number of reasons. Firstly, whilst giving credit to "enlightened" military commanders, they still tend to exaggerate the role of the medical officer vis $\grave{a}$ vis his combatant counterpart. They also exaggerate the military importance of the medical contribution to the war effort which, though considerable, was less marked than the official histories would have us believe. Thirdly, they do not attempt any systematic analysis of the relationship between technological innovation and diffusion in the armed forces. The benefits of new technologies are seen as self-evident and any reluctance to utilize them as proof of the ignorance or incompetence of the commanders concerned. Their story is one of "lessons learnt" and "forgotten", with very little consideration of why these lessons were learnt or forgotten.

*Mark Harrison, DPhil, Department of History, School of Cultural Studies, Sheffield Hallam University, Collegiate Crescent Campus, Sheffield S10 2BP.

This article is a revised and extended version of a paper read at the Malaria and War conference held at the Wellcome Institute for the History of Medicine in
May 1994. I would like to thank all those who participated in the discussion on that occasion, as well as Helen Power, Michael Worboys and the anonymous referees for their valuable comments on the draft. I would like to express gratitude to the Wellcome Trusy for their support whilst researching and writing this article. 


\section{Mark Harrison}

In this article I aim to elucidate the relationship between technological innovation and diffusion ${ }^{1}$ in the armed forces by looking at what might be termed "the culture of command", by which I mean the attitudes, approaches, and styles of leadership that existed in the British Army and the bearing these had on medical services, with special reference to the prevention of malaria. Although medical innovations-such as DDT and new anti-malaria drugs-were important, the British Army's relative success against malaria in the Second World War (by contrast with the First) depended crucially on the emergence of a new style of command which attached greater importance to medicine as a managerial resource. The British Army, like sections of industry ${ }^{2}$ and public administration, ${ }^{3}$ had come to view scientific medicine (broadly construed) as a means of maximizing the potential of manpower. Although occasionally apparent during the First World War, an appreciation of medicine's utility in "man-management" was not widespread among British officers and men until after 1939.

This "managerial" ethos was wedded to a new conception of the British soldier. Senior British officers in 1914-18 generally had a dim view of the ordinary soldier's capacity for independent action and adhered rigidly to a centralized and hierarchical chain of command. ${ }^{4}$ But during the Second World War, a new generation of senior officers, typified by General William Slim and the Adjutant-General Sir Ronald Adam, came to stress the value of education in the maintenance of morale and fighting efficiency. The "citizen-soldier" had a right and a duty to understand where he stood in the scheme of things. Through the films, leaflets and lectures of the Army Education Corps and the Central Council for Health Education, the British soldier was encouraged to take responsibility for his own health and was informed about disease prevention to a far greater extent than in the First World War. ${ }^{5}$ These related developments enable us to explain why the new technologies developed during the Second World War were utilized to their full potential.

1 On the problematic relationship between technological innovation and diffusion, see the essays in John V Pickstone (ed.), Medical innovations in historical perspective, London, Macmillan, 1992.

2 Henry J Welch and Charles S Myers, Ten years of industrial psychology, London, Sir Isaac Pitman, 1932; Irene H Charley, The birth of industrial nursing, London, Baillière, Tindall, 1978; Paul Weindling (ed.), The social history of occupational health, London, Croom Helm, 1986.

3 George Rosen, 'The efficiency criterion in medical care, 1900-1920: An early approach to an evaluation of health service', Bull. Hist. Med., 1976, 50: 28-44; Charles E Rosenberg, 'Inward vision and outward glance: the shaping of the American hospital, 1880-1914', Bull. Hist. Med., 1976, 53: 346-91; Susan Reverby, 'Stealing the golden eggs: Ernest Amory Coleman and the science and management of medicine', Bull. Hist. Med., 1981,
56: 156-71; Abram de Swaan, In care of the state: health care, education, and welfare in Europe and the U.S.A. in the modern era, Cambridge, Polity Press, 1988; Steve Sturdy, 'The political economy of scientific medicine: science, education and the transformation of medical practice in Sheffield, 1890-1922', Med. Hist., 1992, 36: 125-59.

4 Tim Travers, The killing ground: the British army, the western front and the emergence of modern warfare, 1900-1918, London, Unwin Hyman, 1990 edn; idem, How the war was won: command and technology in the British army on the western front 1917-1919, London, Routledge, 1992; idem, 'Command and leadership styles in the British army: the 1915 Gallipoli model', J. contemp. Hist., 1994, 29: 403-42; Denis Winter, Haig's command: $a$ reassessment, London, Viking, 1991, pp. 58-9.

5 See Angus Calder, The people's war: Britain 1939-1945, London, Pimlico, 1992 edn, pp. 250-2. 


\section{The First World War}

Before 1914 the British Army's campaign against malaria had been less than successful: it had lost thousands of men to the disease in the Caribbean in the eighteenth century $^{6}$ and admissions to hospital from malaria in many colonial garrisons did not decrease significantly until the turn of the twentieth century. ${ }^{7}$ Quinine prophylaxiswhich was rumoured to cause sexual impotence - was unpopular with troops and difficult to enforce in peacetime, let alone on active service. There was also much uncertainty about the efficacy of quinine as a prophylactic and concern over its toxic side effects. Nor had control of the mosquito vector-identified by Ronald Ross in 1897-met with much success in the British colonies. Even in strictly controlled areas, such as the military cantonment of Mian Mir in India, results had been disappointing and the practicability of mosquito destruction was hotly contested by advocates of quinine prophylaxis. ${ }^{8}$

There were, however, some encouraging signs: as Philip Curtin has shown, malaria mortality (as opposed to morbidity) in colonial garrisons fell significantly from the midnineteenth century onwards. ${ }^{9}$ Malaria had also been kept in check on some military campaigns: during the Third China War of 1860, the British force was said to have avoided infection by stationing troops in non-malarious areas such as Kowloon; ${ }^{10}$ and, in the Ashanti Wars of $1873-4$, it is claimed that Sir Garnet Wolseley instructed his men in the rudiments of hygiene and that he made sure that "healthy" areas were chosen for the campaign. ${ }^{11}$ British troops were said to have suffered less from malaria than the Ashanti themselves, although other histories of the campaign present conflicting evidence. ${ }^{12}$ But even modest success was the exception rather than the rule: the majority of commanding officers showed little interest in the health of their troops and approached campaigns in malarious areas with a high degree of fatalism.

During the First World War the British Army encountered malaria chiefly in Macedonia, East Africa, Mesopotamia and Palestine. Malaria was not the only health hazard met with in these areas but it was certainly one of the most serious, especially in Macedonia and East Africa. One notable advantage enjoyed by the British Army compared with previous campaigns was the intelligence provided by malaria surveys. The malaria survey-an entomological, topographical and meteorological report-had been developed in India following Ross's identification of the malaria vector. ${ }^{13}$ After the outbreak of war, many of those engaged in mapping malaria in the colonies were seconded

\footnotetext{
6 David Geggus, Slavery, war, and revolution: the British occupation of Saint Domingue 1793-1798, Oxford, Clarendon Press, 1982, ch. 13.

7 David Arnold, Colonizing the body: state medicine and epidemic disease in nineteenth-century India, Berkeley, University of California Press, 1993, p. 76.

${ }^{8}$ Mark Harrison, Public health in British India: Anglo-Indian preventive medicine 1859-1914, Cambridge University Press, 1994, pp. 158-62; W F Bynum, 'An experiment that failed: malaria control at Mian Mir', Parassitologia, 1994, 36: 107-20.

9 See Daniel R Headrick, The tools of empire: technology and European imperialism in the nineteenth century, Oxford University Press, 1981, ch. 3; Philip D
}

\footnotetext{
Curtin, Death by migration: Europe's encounter with the tropical world in the nineteenth century, Cambridge University Press, 1989, pp. 132-40.

10 John Selby, 'The Third China War 1860', in Brian Bond (ed.), Victorian military campaigns, London, Hutchinson, 1967, p. 82.

11 John Keegan, 'The Ashanti campaign 1873-4', ibid., pp. 163-98.

12 See Alan Lloyd, The drums of Kumasi: the story of the Ashanti wars, London, Longmans, Green, 1964 , pp. 77,182 . I am very grateful to Professor Bob Joy for drawing this to my attention.

13 Elizabeth Whitcombe, 'Famine mortality', Econ. Pol. weekly, June 1993, 5: 1169-79; Harrison, op. cit., note 8 above, pp. 158-65.
} 


\section{Mark Harrison}

to the British Army. Among those given temporary commissions in the Royal Army Medical Corps (RAMC) were Sir Ronald Ross, formerly Professor of Tropical Medicine at the Liverpool School of Tropical Medicine; Andrew Balfour, Director of the Wellcome Bureau of Scientific Research; and S R Christophers, British India's foremost malariologist. Balfour was attached to the Medical Advisory Committees of the Mesopotamian and, later, the Mediterranean Areas; ${ }^{14}$ Christophers to the Army in Mesopotamia; and Ross, as Chief Consultant in Malaria, acted as an itinerant adviser.

Using the information gathered in these surveys, campaigns against the insect vector were conducted in most areas occupied by British forces. In the Sinai Desert, at the British base of Kantara, the surrounding countryside was systematically explored and innumerable ponds were filled in or drained. Where this was not possible, petroleum spraying of breeding pools was carried out, apparently with good results. But the most efficient method of destroying larvae was said to be the introduction of larvivorous fish, a method first tried in India. By the end of 1916 it was claimed (somewhat improbably) that one seldom saw a mosquito at Kantara. ${ }^{15}$ Anti-malaria work at Kantara was typical of that conducted at most British bases but more extensive drainage works were also carried out in notoriously malarious areas. This was especially true of parts of Macedonia, where the grave danger posed by malaria was immediately recognized by the Director of Medical Services (DMS) Surgeon-General H R Whitehead when he arrived there in 1915. Ross also visited later that year and recommended the drainage of marshes along the Salonika-Monastir road. By 1916 a team of malaria officers had been appointed to take charge of these operations and mosquito brigades busied themselves clearing streams and destroying larvae-some 1,500 acres of marshland were eventually drained. ${ }^{16}$

In some areas the military authorities showed considerable enthusiasm for anti-malaria measures, especially in southern Mesopotamia, where anti-malaria works were linked to imperialistic ambitions. In 1916, the Medical Advisory Committee, which included the entomologist Andrew Balfour, reported that:

When we come to consider the possibility of anti-mosquito measures on a large scale we are forced to recognise that, in order to be effective, these would probably have to be very extensive and consequently somewhat costly. They will be a necessary corollary of the scheme for land reclamation and town planning which must be carried into effect if Basra is to become a healthy British possession. ${ }^{17}$

Elsewhere drainage operations were less successful, as in the case of the Struma Valleya malarious area into which British troops began to move in 1917. Extensive drainage operations were impossible in mountainous terrain, or where the campaign was a highly mobile one, as in Palestine during 1917-18. The British Expeditionary Force in Palestine had an enviable reputation for good health, owing to the diligence of its commanding

14 For example: 'The medical entomology of Salonika', by Temp. Lt Col Andrew Balfour, RAMC 646, Contemporary Medical Archives Collection, Wellcome Institute for the History of Medicine (hereafter CMAC).

15 Serjeant-Major R.A.M.C. [pseud.], With the R.A.M.C. in Egypt, London, Cassell, 1918, pp. 164-6.
16 DMS Salonika, '(Secret) Report on the incidence of malaria in the Salonika army in 1916; on the measures taken for its prevention; and on the measures proposed for its prevention during 1917', WO 32/5112, PRO.

17 Medical advisory committee, Mesopotamia inquiries: report on Basra base, September 1916, Simla, Govt. Press, 1916, p. 15. 
officer General E H Allenby. But in the autumn of 1918 the British pursued the Turks into the malarious Jordan Valley only to be confronted by propaganda leaflets which warned them that: "The flies all die in Jericho in July, and the men in August". This was not an idle threat, and in the weeks leading up to the armistice with Turkey on the 31 October, almost half the 40,000-strong British force was hospitalized with malaria, much of it of the falciparum (malignant-tertian) variety. ${ }^{18}$

Such difficulties were not the only obstacle to malaria prevention. Many commanding officers were not convinced that much could be achieved by drainage and other such measures, and refused to divert manpower from tasks which they regarded as more essential. At a town not far from Salonika, Captain A Cecil Alport, RAMC, was forced to by-pass his commanding officer and to arrange anti-malaria work through a local major and the French and Serbian commanders. Having gained their support, he secured POWs, civilians and French troops for the construction of a canal to drain the marshes around the town. By the end of the war much of this land was under cultivation and malaria admissions had allegedly decreased to negligible proportions. ${ }^{19}$

Where drainage was not an option, as in mobile campaigns, commanders could always insist that their troops use some form of personal protection, whether in the form of mosquito nets or prophylaxis with quinine. But many MOs were still uncertain about the effectiveness of quinine prophylaxis. Major C H Tredgold, RAMC, serving in Macedonia, noticed that some of the men in his division who had received quinine had resisted illness but that many still fell sick. ${ }^{20}$ Cecil Alport, also serving in Macedonia, was far more pessimistic: in his opinion quinine prophylaxis had been an "absolute failure" and an extra-large dose would be required if it were to have any real effect. Alport believed that it was better to rely upon mosquito nets if possible. ${ }^{21}$ Most other medical officers in Macedonia, including the DMS, General Whitehead, were similarly disillusioned with quinine as a preventive measure. Whitehead reported in 1916 that the results of quinine prophylaxis had been disappointing and that "very many men have contracted malaria who had been taking quinine regularly".22

A sub-committee of the MRC appointed to look into malaria in Macedonia endorsed the opinions of medical officers there. The committee reported in January 1917 that there was "no good evidence that prophylactic quinine has lessened the incidence of malaria". ${ }^{23}$ It should be noted that the committee included both partisans of quinine prophylaxis, such

\footnotetext{
18 'A Mounted Brigade Field Ambulance in peace and war-2nd South Midland Mounted Brigade, 1914-19', RAMC 791/5; Maj. Gen. Sir Richard Luce, 'War experiences of a Territorial Medical Officer', pp. 465, 529-30, 534, RAMC 2031; Memorandum on malaria, p. 5, RAMC 2063/34, CMAC

19 A Cecil Alport, Malaria and its treatment: in the line and at the base, London, John Bale \& Danielson, 1919, pp. 17-22, 25; W G MacPherson and $\mathrm{T} J$ Mitchell (eds), History of the war based on official documents. Medical services general history, vol. 4, Medical services during the operations on the
}

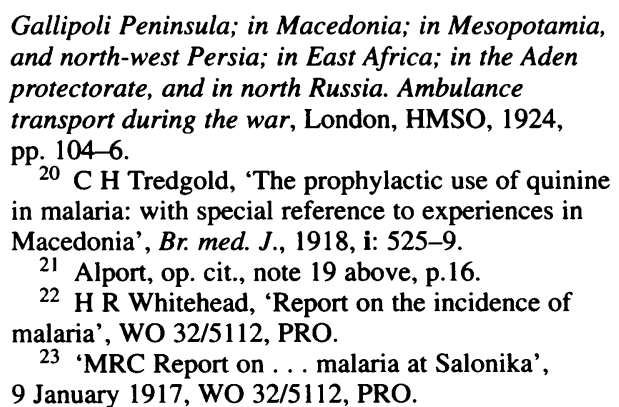




\section{Mark Harrison}

as J W W Stephens, and sceptics like Sir Ronald Ross. ${ }^{24}$ Even before the committee had been appointed, Ross wrote to Sir Alfred Keogh, Director General of the Army Medical Services, that "Experience shows that if mosquitoes are left to abound as before, quinine, even in very considerable prophylactic doses, merely has the effect of keeping down the fever, while allowing the men to become infected". ${ }^{25}$ Although the committee decided that quinine prophylaxis should continue in the most dangerous areas, it placed greater emphasis on the need for drainage and mosquito destruction. ${ }^{26}$ This represented a major professional victory for Ross, whose much vaunted "mosquito brigades" were to form the basis of malaria control in the British Empire until the end of the Second World War.

Yet there were some British MOs who insisted that quinine prophylaxis could be valuable as a routine measure, provided that a standardized dose was given regularly to troops. In S R Christophers' opinion, everything depended on good discipline and expert supervision. ${ }^{27}$ Indeed, it may well have been that the ineffectiveness of prophylaxis during the First World War (and before) was due as much to lax discipline as to the limitations of quinine itself. Commanding officers generally took a relaxed view of such matters and were sometimes reluctant to enforce quinine consumption because of its unpopularity with troops. Thus, although General Allenby provided his force in Palestine with mosquitorepellent ointments and nets, quinine prophylaxis was not compulsory and was left to the discretion of unit commanders. ${ }^{28}$ In Mesopotamia an order was given to compel the prophylactic use of quinine but, as the Advisory Committee reported in 1916, it was "more honoured in the breach than the observance". ${ }^{29}$ Indian troops there were also exempted from the general order insisting on the use of mosquito nets, on the grounds that they were unpopular with the sepoys, who had, in many cases, acquired an immunity to the disease. In Macedonia, quininization of troops and civilian "reservoirs of infection" was attempted but was not strictly enforced, particularly in forward areas. Between January and mid-May 191890 per cent of men in some units on the Struma Front had contracted malaria. ${ }^{30}$

Medical officers often complained that co-operation between medical and other branches of the army was unsatisfactory. The military authorities in Macedonia apparently took little interest in promoting knowledge of malaria among the troops and attendance at lectures on malaria prevention was optional. ${ }^{31}$ A British Medical Journal editorial of March 1918 bemoaned the high incidence of malaria in Macedonia and pointed out that several military operations had been postponed as a consequence. In 1918 alone, some 25,000 British malaria cases were invalided back to the UK. The British Medical Journal claimed that this "wastage" might have been avoided had the General Staff been better

\footnotetext{
24 On the pre-war controversy over quinine prophylaxis and malaria prevention see Michael Worboys, 'Manson, Ross, and colonial medical policy: tropical medicine in London and Liverpool, 1899-1914', in R MacLeod and M Lewis (eds), Disease, medicine, and empire: perspectives on western medicine and the experience of European expansion, London, Routledge, 1988, pp. 21-37; Harrison, op. cit., note 8 above, pp. 158-62.

25 Ross to Keogh, 29 February 1916, WO 32/5112, PRO.

26 'MRC Report on . . . malaria at Salonika': the committee recommended a dose of 5-6 grains every
}

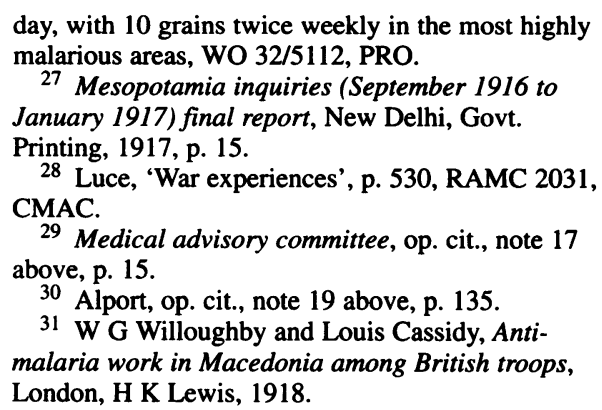




\section{Malaria Control in the British Army}

acquainted with the measures necessary for protection against malaria. ${ }^{32}$ The neglect of anti-malaria discipline was also much criticized in France: quinine prophylaxis was ordered in the French Army in 1916 but was never enforced. Medical officers insisted that this lapse had occurred because combatant officers were not sufficiently aware of the dangers and of what could be done to prevent malaria. A "mission anti-paludique" was sent to Macedonia the following year, with apparently successful results ${ }^{33}$ but such claims must be treated with caution, given the great difficulty of maintaining anti-malaria discipline on active service.

In East Africa the failure of senior commanders to make provisions for malaria prevention had similarly tragic results. Indian troops had been specially chosen for service in East Africa since it was believed they had acquired a degree of immunity to diseases like malaria. It was said that European troops did "not last long in Africa" and that the newly-raised African regiments were not yet a match for the more experienced German colonial troops. ${ }^{34}$ But this supposed immunity was barely apparent: from 8 January to 5 May 1917 there were over 38,000 admissions to hospital among the British-led force in East Africa, an admission rate of 206 per thousand. In fact imperial troops serving in East Africa had a death rate which exceeded that in any other theatre of the war and by the end of the year most of the Indian regiments had been decimated. "The majority", according to General D A Scott (secretary to the Commander-in-Chief of the Indian Army), "were now in very arduous active operations and their wastage is very serious owing to fever, dysentery, casualties in action, exposure and other causes physical and mental peculiar to the campaign. ...."35

But these heavy casualties were not due solely to the perils of climate and terrain. Medical preparations for both the Indian and British East African forces were limited in the extreme and the latter was not even provided with its own medical service until 1917. Malaria surveys (routine in other theatres) were not compulsory in East Africa, nor was the prophylactic use of quinine. As the normally anodyne Official history put it, "It is evident that at this time the prevailing idea was the defeat of the enemy, no matter what the cost in wastage from sickness". ${ }^{36}$ General Jan Smuts-GOC from February 1916 to January 1917-rejected what he termed a "timid Fabian strategy" in favour of arduous marches during which hunger, thirst and sickness were to be met with stoical endurance. Such things were of little consequence, according to Smuts, when the success of a big operation hung in the balance. ${ }^{37}$

However, the high losses suffered by Indian and African forces cannot be attributed to the negligence of Smuts alone. In fact, the deputy GOC East Africa-General L J van Deventer-requested that several IMS officers should be despatched to East Africa to advise on medical arrangements for Indian troops. ${ }^{38}$ But such measures were no more than

$32 \mathrm{Br}$. med. J., 1918, i: 346.

33 See Edmond et Étienne Sergent, L'Armée d'orient délivrée du paludisme, Paris, Librairie de l'Académie de Médicine, 1932, pp. 41-5, 59, 77.

34 GOC East Africa to Chief of Imperial General Staff, 20 July 1917, L/MIL/5/737, India Office Records (IOR).

35 Scott to Robertson, 14 November 1917 , L/MIL/5/737, IOR.

\footnotetext{
36 MacPherson and Mitchell (eds), op. cit., note 19 above, p. 466.

37 F S Grafford, Jan Smuts: a biography, London, George, 1946, pp. 129-30.

38 Viceroy to Secretary of State for India, 11 September 1917, L/MIL/5/737, IOR.
} 
a palliative since the real need, as General Scott pointed out, was for the replacement of disease-ridden regiments with fresh troops from India (the 12,000 white South African troops serving in East Africa had already been withdrawn). "All Indian units here", he urged, "should be given a period of complete rest in a suitable climate and surroundings with special medical supervision, good food, ample milk, fresh vegetables, comfortable clothing, and these cannot be secured in East Africa." His own preference was to decamp to Nairobi, where the climate and accommodation were more congenial. ${ }^{39}$ General van Deventer was of like mind, pointing out that the frontier unrest which had kept many regiments tied to India had been settled, there now being no good reason why Indian troops in East Africa should not be relieved. ${ }^{40}$ Yet the Commander-in-Chief in India still refused "on account of the excessive wastage amongst Indian troops which occurs there and of the shortness in India of trained men to form the nucleus of a trained battalion. Briefly ... we believe that Indian troops are unsuited for service in East Africa and could be profitably employed elsewhere". 41 This was no doubt good news for the regiments still in India but for those in East Africa it was little short of a death sentence.

The failure to control malaria in East Africa drew a good deal of criticism in Britain: questions were asked in the House of Commons about sickness among troops and reassurances sought from the Under-Secretary for War. ${ }^{42}$ The British Medical Journal also stressed the urgent need for anti-malaria discipline and the education of troops in preventive measures. Its editor was particularly concerned about the ordinary soldier's "prejudice" against quinine and his apparent reluctance to use mosquito nets. ${ }^{43}$ Medical provisions in East Africa improved slowly_probably as a result of these protests-but it was a case of too little too late. Malaria control was taken seriously only in the later phases of military operations, by which time the troops were already saturated with infection. ${ }^{44}$

\section{The Second World War}

At the outbreak of the Second World War, most medical officers still endorsed Ross's view that quinine could only suppress, not prevent, malarial infection. Consequently, the interwar literature on malaria prevention in the British and Imperial forces had been concerned almost entirely with mosquito destruction and drainage ${ }^{45}$ and MOs were advised not to rely too heavily on "suppressive treatment", as the preventive use of quinine was now termed. A memorandum issued to British forces in the Middle East in 1942 stated that suppression was an emergency measure, to be contemplated only when other measures were impracticable. ${ }^{46}$ In many theatres of the war, supplies of quinine were, in any case, intermittent, especially when an army was in retreat. ${ }^{47}$

39 Scott to Robertson, 14 November 1917 , L/MIL/5/737, IOR.

40 Van Deventer to Robertson, 20 July 1917, L/MIL/5/737, IOR.

41 Commander-in-Chief, India, to Robertson, 16 July 1917, L/MIL/5/737, IOR.

42 See for example, Hansard, Parl. debates, 19 July 1917; question from Mr Molteno, MP.

43 Br. med. J., 1916, i: 100.

44 W G MacPherson, W P Herringham, T R Elliott, and A Balfour, Medical diseases of the war,



47 'Medicine in jungle warfare', reprint from Procs. r. Soc. Med., March 1945, 38: 195-8, RAMC 1939, CMAC. 


\section{Malaria Control in the British Army}

In 1942, following the Japanese invasion of the Dutch East Indies, the main source of quinine was closed to the Allies and attention began to turn to synthetic substitutes. One such substitute was mepacrine (also known as atebrin); a substance which had been synthesized by German chemists in the early 1930s. Successful field trials aroused German hopes that it would give their forces the edge in any war in Africa or the Mediterranean. But the Germans had sold the secrets of the new drug to the Americans and, although this information omitted vital details, it had allowed the Americans and the British to synthesize small quantities of mepacrine before the war began. With the entry of America into the war in 1941, and the fall of Java to the Japanese in the following year, British, American and Dominion chemists stepped up production of the drug, which was made available to front-line units from $1942 .{ }^{48}$

But mepacrine prophylaxis initially fared no better than quinine. After being used in West and North Africa in 1942-3, its use was discontinued in some areas because of its allegedly toxic side effects. ${ }^{49}$ However, some MOs claimed that the real problem was not mepacrine itself but the continuing hostility of combatant officers and men. The replacement of quinine with mepacrine had failed to scotch rumours circulating in both the British and Indian armies regarding anti-malarial drugs and sexual impotence. Suspicion of anti-malarial drugs was also heightened in India by reports of the death of twelve soldiers in the Eastern Army as a result of the intravenous injection of large "therapeutic" doses of quinine. ${ }^{50}$

Such reservations were not easily dispelled, despite considerable effort on the part of the military authorities. In North Africa during 1942, the British forces' newspaper Union Jack conducted a long educational campaign among British troops which stressed their responsibilities towards their comrades in arms. "Every soldier", it insisted, "should be aware that in becoming a malaria casualty, through neglect of [anti-malarial] precautions he is wilfully endangering his healthy neighbour because of his own infection". 51 Neglecting to take one's mepacrine amounted to a crime against one's fellows: "Any soldier who steals from a comrade has sunk pretty low", declared the Union Jack, "Yet that is exactly what scores are doing right now in this theatre of war. . . Through thoughtless stupidity and not through malice. But that doesn't let them out." 52 In India, too, instructions urged that "Strong disciplinary action should be taken against those who fail to carry out routine prophylactic measures during the malaria season. Failure to observe such measures is tantamount to self-inflicted injury". 53

The invasion of Sicily in the summer of 1943, during which over 20,000 British troops were admitted to hospital with malaria, showed that such appeals had had little effect. Many officers failed to take any precautions against malaria and numerous cases occurred among the British force even before it had left North Africa (almost 500 men were left

\footnotetext{
48 Papers of Sir Ernest Covell: circular letter on the health of the army in North Africa in 1942, p. 8, RAMC 466/38, CMAC.

49 Maj. J Reid, 'Studies on the pharmacology of mepacrine', p. 1, RAMC 2065, CMAC.

$50 \mathrm{Col}$ G F Taylor, 'Some medical problems of the Eastern Army', Proceedings of the conference of medical specialists of Eastern Army, March 1943, Calcutta, Govt. of India Press, 1943, pp. 7-10.
}

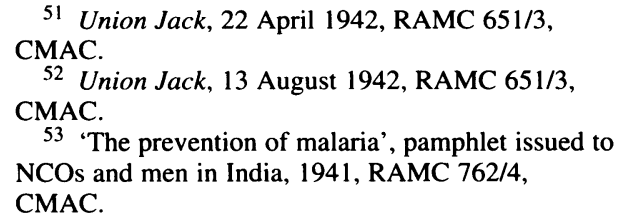

51 Union Jack, 22 April 1942, RAMC 651/3, CMAC.

52 Union Jack, 13 August 1942, RAMC 651/3, CMAC.

53 'The prevention of malaria', pamphlet issued to NCOs and men in India, 1941, RAMC 762/4, CMAC. 


\section{Mark Harrison}

behind by the 7th Army alone). In Sicily the situation was even worse: malaria units did not arrive until very late in the day and mepacrine suppression was never enforced. ${ }^{54}$ Nor were the troops encouraged by their officers to use mosquito nets or insect repellents, as both were generally unpopular. ${ }^{55}$ Troops had been instructed in malaria prevention but too much of their training was theoretical. The military authorities also made a number of errors and misjudgements, some of which had lasting consequences: troops were issued with shorts which left their legs exposed to mosquito bites in the evening; instructions regarding mepacrine suppression were misleading, giving the impression that the drug was to be taken for five weeks only; an older and more greasy type of protective cream was issued, instead of the newer one that had been authorized. According to Lt-Col A S Thompson, the latter error was "the origin of a prejudice against repellents of any kind, which lingered to the end of the war. Men who had been in Sicily swore that "antimosquito cream" actually attracted mosquitoes". 56

But an even more fundamental obstacle stood in the way of malaria control: the indifference and even hostility to anti-malaria precautions displayed by those in positions of responsibility. The Deputy Director of Hygiene for the Middle Eastern Command declared that "junior officers and senior N.C.Os. set a particularly bad example as regards individual measures of protection. ... It was also very clear that formation staffs were not blameless. ... It was widely reported that one area commander was notorious for his disregard of personal anti-malaria precautions". 57 Such neglect left a legacy which contributed to the high incidence of malaria that persisted into the first three weeks of the campaign in mainland Italy. From 4 September to 27 November there were no less than 15,547 cases of malaria and Not Yet Diagnosed Fevers admitted to medical units of the 8th Army; at least 8,000 of which were attributed to infection in Sicily. ${ }^{58}$

The urgent need to stem the drain on manpower caused by malaria in. Italy and the Eastern Theatre led, in 1943, to the formation of the Australian Army Medical Research Units, based at Cairns and Atherton in Northern Queensland. At Cairns, under Brigadier $\mathrm{N}$ Hamilton Fairley, volunteers were subjected to bites from mosquitoes infected with malaria and treated with various anti-malarial drugs. At Atherton, a non-malarious area, scientists investigated whether patients infected at Cairns had been cured, or still harboured parasites in their blood. Among the drugs tested were sulphamerazine, mepacrine, and a new compound, paluride, which did not come into general use until after the war. ${ }^{59}$

The Cairns work, together with research carried out at the Royal Army Medical College, Millbank, showed that mepacrine was not toxic if taken in small $\operatorname{doses}^{60}$ and subsequent use was to reveal that semi-serious side effects, such as dermatitis, occurred in

\footnotetext{
54 'Memo. on anti-malarial discipline', RAMC 1900/14/5; Covell papers: 'Malaria in the Sicilian campaign 9 July-10 September 1943', RAMC 466/36, CMAC.

55 John Ellis, The sharp end of war: fighting man in World War II, London, David \& Charles, 1980, pp. $183-4$.

56 Lt-Col A W S Thompson, 'Malaria control in mobile warfare-Italian campaign 1943-45', pp. 5-6, WO 222/159, PRO.
}

\author{
57 Ibid., p. 7. \\ 58 Ibid., p. 8. \\ 59 N Hamilton Fairley, 'Researches in malaria \\ therapy (secret)', RAMC 1939/6; 'Researches on \\ Paluride (M.4888) in Malaria', reprinted from Trans. \\ r. Soc. trop. Med. Hyg., 1946, 40: 105-53. \\ 60 Maj. J Reid, 'Studies on the pharmacology of \\ mepacrine', RAMC 2065, CMAC.
}




\section{Malaria Control in the British Army}

only a small number of cases, although yellow staining of the skin was fairly widespread. ${ }^{61}$ But the real value of this research, together with experience in the field, ${ }^{62}$ was that it demonstrated that mepacrine was effective against all forms of malaria. The conclusion, accepted with some reserve by the General Staff, was that problems encountered in malaria prevention were due not to any defect in the drug but to lapses in anti-malarial discipline. ${ }^{63}$ Strict discipline, as a memorandum of 1944 put it, was now identified as "the essence of successful anti-malarial measures". ${ }^{4}$

The truth of this maxim was amply demonstrated in both positive and negative senses by developments in the last two years of the war. In 1945 Fairley observed approvingly that the malaria rate among the Australian force in New Guinea had declined progressively from 740 per 1000 in December 1943 to only 20 per 1000 by November 1944 , despite the fact that troops were still stationed in hyper-endemic areas. ${ }^{65} \mathrm{He}$ believed that this improvement had been achieved by tightening mepacrine discipline and by better education of combatants in malaria prevention. By the end of the war, the Australian Army had come to regard knowledge of mepacrine administration and other anti-malarial measures as "an essential part of a soldier's training for jungle warfare", and their implementation as "a matter of strict military discipline". 66

Another striking illustration of what could be achieved through discipline was the successful campaign against malaria in South East Asia. General Slim, commanding the 14th Army (a British, Indian, and African force), is generally remembered for repelling the Japanese invasion of Arakan in 1944 and the reconquest of Burma the following year. Malaria control was to play a crucial part in the campaign, and, in his memoirs Defeat into victory, Slim rated health as his most important problem after supply. In 1943 the malaria rate averaged 60 per cent of the total strength of his Army, and was considerably higher among forward troops. The Indian 6th Infantry Brigade operating in Arakan at the beginning of 1943 suffered a 100 per cent infection rate, ${ }^{67}$ and in the last three months of that year, some 18,000 British malaria cases were evacuated from India. ${ }^{68}$ Slim's solution was to put pressure upon unit commanders. As he put it:

Good doctors are no use without good discipline. More than half the battle against disease is fought not by doctors, but by regimental officers. It is they who see that the daily dose of mepacrine ... is

61 V Zachary Cope (ed.), Medical history of the Second World War. Medicine and pathology, London, HMSO, 1953, p. 200.

62 Several field trials were carried out using mepacrine. See for example Fairley Papers, US Army field experiment on suppressive treatment, RAMC 1939/7, CMAC.

63 F H K Green and Sir Gordon Covell (eds), Medical research. Medical history of the Second World War, London, HMSO, 1953, pp. 158-9; N Hamilton Fairley, 'Tropical diseases with special reference to malaria in the eastern theatres of war', in Sir Henry Letheby Tidy (ed.), Inter-allied conferences on war medicine 1942-1945. Convened by the Royal Society of Medicine, London, Staples Press, 1947, pp. 94-5.

64 'Memo. on anti-malarial discipline', RAMC 1900/14/5, CMAC.
65 N Hamilton Fairley, 'Medicine in jungle warfare', p. 198, RAMC 1939/7, CMAC.

66 N Hamilton Fairley, 'Chemotherapeutic suppression and prophylaxis of malaria: an experimental investigation undertaken by medical research teams in Australia', Trans. r. Soc. trop. Med. Hyg., 1945, 38: 349; Sir Neil Cantlie, 'Health discipline', U.S. armed Forces med. J., 1950, i: $233-4$.

67 'The medical services with 2 nd Division during operations for the capture of Kohima and the opening of the Diamapur-Kohima-Imphal Road, April-June 1944', p. 58, RAMC 814, CMAC.

68 F A E Crew, The army medical services. Campaigns, vol. 5, Burma, London, HMSO, 1966, p. 617. 


\section{Mark Harrison}

taken ... If mepacrine was not taken, I sacked the commander. I only had to sack three; by then the rest had got my meaning. ${ }^{69}$

On the advice of the Consultant Malariologist, India Command, Major-General Sir Gordon Covell, mepacrine suppression was enforced with vigour throughout Burma. Covell had visited Cairns and New Guinea, and had seen the results of effective suppression at first hand. ${ }^{70}$ Slim also had the support of Lord Mountbatten, who assumed supreme command of Allied forces in South East Asia in 1943. Mountbatten took a personal interest in medicine and began a vigorous onslaught on the Indian administration to secure better medical provisions; ${ }^{71}$ although there remained some problems with the supply of mepacrine during mobile operations. ${ }^{72}$ Education in mepacrine suppression was also stepped up, apparently with good effect. A report on malaria in the British force during operations in Arakan from March to June 1943 claimed that "In spite of the usual barrack-room rumours that the drug caused impotence, men came to place considerable reliance on it, and infantrymen would come to the R.A.P. [Regimental Aid Post] for the drug if they had missed it for any reason". The only problem was that the new regime imposed by Slim, which involved daily parades at which the drug was distributed by company, platoon and section commanders, was liable to be upset by active service. ${ }^{73}$

Despite these difficulties, Slim's determination to overcome the problem of malaria gradually bore fruit. Admissions to hospital from malaria among British soldiers in Burma decreased from a high of 60 per cent of total strength in 1943 to around 10 per cent in 1945. The death rate was also greatly reduced, and from May 1944 to November 1945 it is claimed that there were only 6 deaths out of almost 14,000 cases. ${ }^{74}$ Some caution is advisable when assessing these figures, for it is doubtful whether many malaria cases were in a position to be evacuated and therefore admitted to hospital. Yet it was clear to most observers that improved anti-malarial discipline had given the Allies the edge in Burma. Increasing confidence in malaria control enabled Mountbatten and Slim to continue their advance through the monsoon, when the malaria season was at its height. ${ }^{75}$ The Japanese, by contrast, were gravely weakened by malaria, and blood samples obtained from captured Japanese soldiers revealed rates of infection ranging from around 30 to 49 per cent. ${ }^{76}$ The supply of medicines and other vital equipment to the Japanese Army had broken down and anti-malaria discipline lapsed as the army retreated. ${ }^{77}$

Anti-malaria discipline undeniably gave the Allies a comparative advantage over the Japanese but it is necessary to qualify some of the more extravagant claims made by medical officers after the event. The DGAMS of the Indian Army, for example, gave

\footnotetext{
69 Field-Marshal Sir William Slim, Defeat into victory, London, Cassell, 1956, p.180.

70 Green and Covell, op. cit., note 63 above, p. 159; Crew, op. cit., note 68 above, pp. 645-6.

71 Philip Ziegler, Mountbatten: the official biography, London, Collins, 1985, pp. 250-1.

72 Crew, op. cit., note 68 above, p. 645.

73 Major R Bevan, 'Malaria in 6th Infantry Brigade, Arakan operations', p. 13, WO 222/150, PRO.

${ }^{74} \mathrm{~W}$ Franklin Mellor (ed.), Medical history of the Second World War: casualties and medical statistics, London, HMSO, 1972, p. 389; 'Fourteenth Army, medical history of the Burma campaign, November
}

1944-May 1945', pp. 44-9, 71, RAMC 1117 , CMAC.

75 Ziegler, op. cit., note 71 above, pp. 250-1.

76 Crew, op. cit., note 68 above, p. 647; 'The medical services with 2nd Division', p. 61, RAMC 814, CMAC.

77 Peter Calvocoressi, Guy Wint, and John Pritchard, Total war: the causes and courses of the Second World War, vol. 2, The greater east Asia and Pacific conflict, London, Penguin, 1989 edn, p. 534; George MacDonald Fraser, Quartered safe out here: a recollection of the war in Burma, London, Harvill, 1992 , p. 162. 


\section{Malaria Control in the British Army}

credence to the popular belief that Slim and Mountbatten had deliberately chosen as their battleground the most malarious areas of Burma in the knowledge that their medical services were infinitely superior to those of the Japanese. Slim denied this in his autobiography and disclosed that he was still far from confident about his army's precautions against malaria. It was this lingering doubt about the success of the antimalaria campaign that led Slim to chose East African troops to lead the force into the Kabaw Valley, on account of their (supposedly) greater immunity to the disease. He further maintained that any superiority his medical service may have enjoyed was not due to any greater professionalism on its part but merely to the fact that the Japanese Army was starved of supplies and in disarray from its hasty retreat. ${ }^{78}$

Although the results of mepacrine suppression were impressive, malaria control was not simply a matter of personal protection. Where conditions permitted, mosquito eradication measures of various kinds were implemented, including traditional methods such as the oiling of breeding pools, as well as the use of insecticide sprays more appropriate to mobile warfare. Between the wars, the insecticide Paris Green (first used against the Colorado beetle in the USA) came to be employed against mosquitoes in the British colonies. ${ }^{79}$ However, in the years immediately before the war, pyrethrum-based insecticides took pride of place. The only drawback with pyrethrum was that it was extracted from flowers which grew mostly in Dalmatia and Japan, and at the outbreak of war the Allies were left with Kenya as the sole supplier. Since Kenyan supplies were insufficient, a substitute had to be found and this came in the form of dichlorodiphenyltrichloroephane (DDT), first synthesized by a German chemist in 1874 . The insecticidal properties of DDT were not discovered until 1939, after which tests were conducted in the USA and in Britain to determine its uses and its toxicity. Even then, there was some delay before the substance was being used in the field and the first large-scale use of DDT did not occur until the beginning of 1944, during the Naples typhus epidemic. Subsequently, field trials which tested the efficacy of DDT against mosquitoes were conducted in India and in the South West Pacific by US forces. ${ }^{80}$

The success of these trials led to the widespread use of DDT in malaria control and it was to prove especially important in Italy, where as a result of war damage and deliberate sabotage by the Germans large areas of reclaimed coastal land had been flooded. The Germans had also sabotaged the canals draining land north of Naples, as well as the drainage system of the Pontine Marshes, which lay in front of the Allies as they advanced towards Rome. It seemed as if malaria was being used consciously as a weapon of war. ${ }^{81}$

78 Slim, op. cit., note 69 above, p. 354. B L Raina (ed.), Official history of the Indian armed forces medical services in the Second World War 1939-45. Medical services: campaigns in the eastern theatre, New Delhi, Combined Inter-Services Historical Section, India \& Pakistan, 1964, forward by C C Kapila, DGAMS Indian Army.

99 League of Nations Health Organisation, Malaria Commission, Report of the malaria commission on its study tour in India (August 23rd to December 28th, 1929), Geneva, League of Nations, 1930 , p. 51. On the introduction of Paris Green to Britain see J F M Clark, 'Eleanor Ormerod
(1828-1901) as an economic entomologist: "pioneer of purity even more than of Paris Green"', Br. J. Hist. Sci., 1992, 25: 413-52.

80 Green and Covell, op. cit., note 63 above, pp. 160-1; J B Coates (ed.), Communicable disease, malaria. Medical department, U.S. army, preventive medicine in world war II, Washington, Office of the Surgeon General, Dept of the Army, 1952.

81 C R S Harris, History of the Second World War. Allied military administration of Italy 1943-1945, London, HMSO, 1957, pp. 424-5; Union Jack, 4 May 1944, RAMC 651/3, CMAC. 


\section{Mark Harrison}

However, the expected epidemic among both civilians and soldiers never occurred. This was due, in part, to the improvement of anti-malarial discipline after the Sicilian campaign and partly to the use of DDT, which kept malaria under control outside of military camps. A Malaria Control Branch was set up under Colonel Paul Russell of the US Army Medical Corps to act in an advisory capacity to the Allied armies and civilian public health bodies. Russell and his colleagues showed that DDT could be used both as a larvicide and in the destruction of adult mosquitoes, and that it could be sprayed by hand or by aircraft; the latter being particularly useful in flooded areas like the Pontine Marshes. It was also discovered that buildings sprayed with DDT remained lethal to adult mosquitoes for up to two months. This was of great importance from a military point of view, for it provided a method of control which enabled fast-moving forces to be protected in forward areas. ${ }^{82}$ Combined with suppressive treatment with mepacrine and more vigorous propagandizing, these measures reduced the malaria rate in the Central Mediterranean Force from 76 per 1000 in 1944 , to 19 per 1000 in $1945 .^{83}$

DDT also figured prominently in malaria control in Burma. Anti-Malaria Units had formerly been dependent upon the insecticide Paris Green and upon drainage works, where these were practicable. The units had been fairly successful in keeping malaria in check around the base camps but they had been unable to confer much protection on troops in forward areas. ${ }^{84}$ By the time of the Slim's invasion of Burma, the spraying of DDT from the air was common and specially-adapted Hurricane fighters covered large tracts of land prior to the advance of Allied troops. A classic example was the spraying of the Kabaw Valley (literally, "valley of death"), which was said to be "one of the most unhealthy areas in the world" because of the prevalence of both scrub typhus and malaria. Allied troops had to move through this area immediately after the monsoon of 1945 but spraying kept sickness to a minimum. ${ }^{85}$ Such achievements led some MOs to anticipate the eradication of malaria but success brought its own problems. A report on the medical history of the Burma campaign recorded "a growing tendency in Units to consider that D.D.T. abolished the necessity for observance of $100 \%$ hygiene standards". "Such was the publicity", the report claimed, "it was thought D.D.T. would convert a hopelessly insanitary area into a health resort."86

And it was true that there were still officers and men who paid little heed to medical advice. A case in point is Special Force (better known as the "Chindits") which operated behind Japanese lines in Burma. Suppressive treatment with mepacrine and other personal measures were the only feasible means of protecting the long-range penetration columns of Special Force against malaria. But, according to the Chief MO, Colonel William J Officer, its columns were not supplied with mepacrine, protective clothing, insect repellent, or nets, until very late in the day. Even then, these articles were not always put to effective use.

\footnotetext{
82 Harris, op. cit., note 81 above, pp. 425-6; Covell papers: War diary, 7, 21, and 29 December 1943, RAMC 466/38; Medical circular, 11 December 1943, RAMC 466/36, CMAC; Thompson, 'Malaria control', pp. 9-10, WO 222/159, PRO.

83 Statistical report on the health of the army 1943-1945, London, HMSO, 1948, p.7, tables 234-5; Harris, op. cit., note 81 above, p. 426; 'Report on malaria in Italy, 24 January 1944', p. 1, RAMC 651/2, CMAC.

${ }^{84}$ Crew, op. cit., note 68 above, p. 642; 'The
}

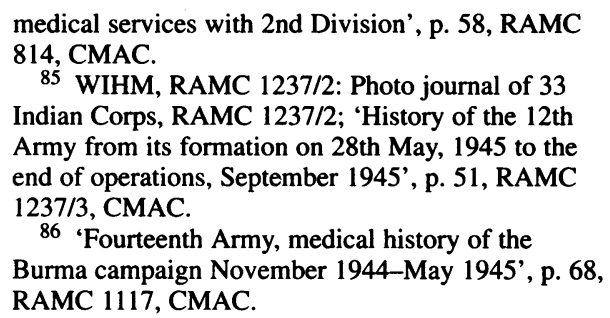




\section{Malaria Control in the British Army}

"Antimalarial discipline", he lamented, "was of a very low standard"; a fact which he put down partly to the ordinary soldier's suspicion of mepacrine and partly to a belief on the part of some officers that it reduced fighting efficiency. ${ }^{87}$ In addition, there was a deeply ingrained distrust of MOs: according to Captain J S Dawson, "the habit of looking upon the doctor as a Fifth Columnist, likely to blab the merest piece of confidential information vouchsafed to him, is still all too prevalent". ${ }^{88}$ But education in malaria prevention was not totally without success. One MO reported that mepacrine was popular with the troops in his column and that they took care to store it up, as with ammunition. ${ }^{89}$

Colonel Officer believed that the neglect of malaria control in Special Force was chiefly the fault of its commander-Major-General Orde Wingate. Wingate had an undisguised contempt for medicine and medical officers: like some Victorian commanders, he believed that MOs knew little about warfare and regarded them as little more than an encumbrance on active service. Colonel Officer's predecessor claimed that "the Medical Branch had to fight at every stage for even the smallest concession to the medical care of the troops" and spoke of Wingate's "antipathy to all things medical". On their first meeting, Wingate told him frankly that he did not want anything medical with his columns but that he would acquiesce in a doctor for each "for the sake of the moral effect on the families at home". He wanted every man with his force to be a fighting man, with "no passengers nor Geneva Convention people". 90 It was alleged that Wingate remained wilfully ignorant of the condition of his men, ${ }^{91}$ despite reports that malaria was sapping the morale and fighting efficiency of the force.

The contrast between medical provisions in Slim's 14th Army and Wingate's Chindits could not be more striking. These differences may be attributed partly to the nature of the campaign: operating behind the lines; the Chindits did not have the benefit of either mosquito brigades or aerial spraying with DDT. The areas in which they fought were also intensely malarious and even where mepacrine suppression was rigorously enforced, levels of infection were such that the dosage had to be increased considerably, and not always with great success. ${ }^{92}$ But Wingate cannot escape responsibility for the high sickness rate in his force: he was clearly antagonistic towards MOs and did nothing to encourage an interest in malaria prevention among his officers or men. Indeed, Wingate was heavily criticized for his neglect of medical arrangements by an official report issued in $1945 .{ }^{93}$ Slim, by contrast, was the very model of the new professional soldier: strict yet compassionate, and keen to apply the principles of "man-management" and "manpower economy". He was also ready to take advice from experts, whereas Wingate was imperious and refused to listen to or to defer to anyone. ${ }^{94}$ Wingate was convinced that victory could be gained only by sacrifice and, like an Old Testament prophet, promised doom and oblivion to all those who served under him. ${ }^{95}$

87 'Special Force. Report on the medical aspects of operations for the period 1943-4', by the DDMS, Col W J Officer, pt 4, pp. 8-10, RAMC 816, CMAC.

88 'Report by Capt J S Donovan', RAMC 816, CMAC.

89 'Some observations of a column medical officer', RAMC 816, CMAC.

90 'Notes on the Report by the former DDMS', RAMC 816, CMAC.
91 Ibid., p.3.

92 'Special Force', pt 6, p. 10, RAMC 816, CMAC.

93 'Report on medical provisions for the Burma

Field Force, 1943-45', RAMC 2021, CMAC.

94 Shelford Bidwell, The Chindit war: the campaign in Burma, 1944, London, Book Club Associates, 1979, p. 39.

95 Ibid., pp. 24, 39, 41, 62. 


\section{Mark Harrison}

\section{Conclusion}

The campaign in Burma serves to underline the point that success in malaria controlas in other areas of military medicine-depended crucially upon the value attached to medicine by commanders in the field. Although the link between medicine and military efficiency was clearly perceived by generals such as Wolseley in the nineteenth century, the British Army was slow to incorporate medicine into military planning. The situation began to change during the First World War, as manpower shortages provided an incentive to cut down on "wastage" from disease, but it was clear that medical officers were often excluded from military decision-making and that medicine was given a low priority by headquarters staff (away from the Western Front, at least).

During the Second World War a new generation of senior commanders such as Slim, inured to principles of manpower economy and with personal experience of the Army's medical failures in the First World War, came to attach much greater importance to medical provisions for troops. This new style of command was a crucial factor in the British Army's relative success against malaria after 1943; as it was in other Allied armies. The success of mepacrine suppression depended on a readiness to impose discipline on regimental officers, while the successful use of DDT depended on closer co-operation between medical and combatant branches of the army. But discipline and planning are only part of the story: a concerted effort was made to educate troops in malaria prevention and to make personal precautions a matter of military honour. Soldiers were instructed in malaria prevention during the First World War but these attempts were often half-hearted, for there was little faith in the ordinary soldier's capacity for education and self-discipline. During the Second World War, by contrast, it was made clear that the prevention of malaria was as much the responsibility of the soldier as of the medical officer. Although this new faith in the British soldier was not entirely justified in view of the neglect of antimalaria precautions in Sicily and North Africa, there is some evidence to suggest that mepacrine may have been growing in popularity by the end of the war and that malaria prevention was becoming a standard feature of military training.

Paradoxically, the greater ability of armies to control malaria during the Second World War made the disease a more important factor in military operations. Whereas, previously, opposing forces had usually been affected by the disease in equal proportion, it was now possible for an army which took malaria control seriously to gain a comparative advantage; a feature of the Second World War which is clearly illustrated by the campaign in South East Asia. F A E Crew, the official medical historian of the Burma campaign, went so far as to suggest that the marked difference in malaria rates in the opposing forces was "one of the most important reasons why the Japanese were defeated". 96 There is some truth in this but it is important to note that the medical advantage enjoyed by the Allies at this stage of the war owed as much to the military situation as it did to medical intervention and anti-malaria discipline, and particularly to the fact that Japanese supply lines had been disrupted by the retreat of their army and by superior Allied air-power. As Slim readily acknowledged, if the situation had been reversed, his army's medical advantage would have quickly disappeared.

96 Crew, op. cit., note 68 above, p. 647. 